\title{
Comparison of diagnostic and treatment guidelines for undescended testis
}

\author{
Jaeho Shin, MD', Ga Won Jeon, MD, PhD ${ }^{2}$ \\ ${ }^{1}$ Division of Pediatric Surgery, Department of Surgery, Inje University Busan Paik Hospital, Busan, Korea; ${ }^{2}$ Department of Pediatrics, Inje University Busan Paik \\ Hospital, Inje University College of Medicine, Busan, Korea
}

Cryptorchidism or undescended testis is the single most com mon genitourinary disease in male neonates. In most cases, the testes will descend spontaneously by 3 months of age. If the testes do not descend by 6 months of age, the probability of spontaneous descent thereafter is low. About 1\%-2\% of boys older than 6 months have undescended testes after their early postnatal descent. In some cases, a testis vanishes in the abdomen or reascends after birth which was present in the scrotum at birth. An inguinal undescended testis is sometimes mistaken for an inguinal hernia. A surgical specialist referral is recommended if descent does not occur by 6 months, undescended testis is newly diagnosed after 6 months of age, or testicular torsion is suspected. International guidelines do not recommend ultrasonography or other diagnostic imaging because they cannot add diagnostic accuracy or change treatment. Routine hormonal therapy is not recommended for undescended testis due to a lack of evidence. Orchiopexy is recommended between 6 and 18 months at the latest to protect the fertility potential and decrease the risk of malignant changes. Patients with unilateral undescended testis have an infertility rate of up to $10 \%$. This rate is even higher in patients with bilateral undescended testes, with intra-abdominal undescended testis, or who underwent delayed orchiopexy. Patients with undescended testis have a threefold increased risk of testicular cancer later in life compared to the general population. Self-examination after puberty is recommended to facilitate early cancer detection. A timely referral to a surgical specialist and timely surgical correction are the most important factors for decreasing infertility and testicular cancer rates.

Key words: Anorchia, Cryptorchidism, Fertility, Orchiopexy, Testicular neoplasm

\section{Key message}

Primary caregivers should consider surgical specialist referral of patients with undescended testis if no descent occurs by 6 months, undescended testis is newly diagnosed after 6 months of age, or testicular torsion is suspected. Orchiopexy is recommended between 6 and 18 months at the latest. The original location of the testes and the age at orchiopexy are predictive factors for infertility and malignancy later in life.

\section{Introduction}

Cryptorchidism or undescended testis (a testis that is not in the scrotum) is the single most common genitourinary disease in male neonates. ${ }^{1)}$ Normal testicular descent to the scrotum usually occurs between 25 and 35 weeks of gestation. ${ }^{2}$ Undescended testis is diagnosed at birth at a rate of $1 \%-4 \%$ in term infants and up to $45 \%$ in preterm infants. ${ }^{3)}$ Many cases of undescended testes will descend spontaneously to the scrotum by 3 months of age. ${ }^{4)}$ Testicular descent after 3 months of age is also possible, especially in preterm infants. ${ }^{5}$ However, in some preterm infants, the testes do not descend until term age or vanish in the abdomen. In some cases, a testis that was present in the scrotum reascends after birth. The mechanisms of normal testicular descent, testicular reascent, and testicular regression have not been fully established yet. About $1 \%-2 \%$ of boys older than 6 months develop undescended testis after its early postnatal descent. $\left.{ }^{6}\right)$ Undescended testis is known to be associated with decreased fertility and increased malignancy rates. ${ }^{7,8)}$ Timely referral to a surgical specialist and timely surgical correction may improve fertility rates and decrease malignancy rates related to undescended testis. Controversy persists about the effectiveness of hormonal therapy, timing of surgical therapy, and testicular outcomes of undescended testis. In this review, we discuss the diagnosis, differential diagnosis, hormonal therapy, and timing of surgical therapy of undescended testis based on international guidelines as well as fertility and the risk of testicular cancer of undescended testis.

\footnotetext{
Corresponding author: Ga Won Jeon, MD, PhD. Department of Pediatrics, Inje University Busan Paik Hospital, Inje University College of Medicine, 75 Bokji-ro, Busanjin-gu, Busan 47392, Korea 


\section{Risk factors}

Important risk factors of undescended testis are preterm birth ( $<37$-week gestation), low birth weight $(<2.5 \mathrm{~kg})$, and intrauterine growth restriction. ${ }^{9)}$ A family history of undescended testis, associated hormonal disorders (such as congenital adrenal hyperplasia), associated penile abnormalities (such as hypospadias), slow fetal growth (such as Down syndrome), and disorders of sex development can increase the risk of undescended testis. A young maternal age is protective against the development of undescended testis. ${ }^{10)}$ Older maternal age is related to undescended testis. ${ }^{11)}$ The relative risk is 1.8 with a maternal age $\geq 30$ years and 2.5 with a maternal age $\geq 40$ years. However, controversy persists regarding the role of maternal old age and the development of undescended testis. Maternal smoking during pregnancy is associated with an increased risk of undescended testis. ${ }^{12,13)}$ A history of previous surgery for inguinal hernia or orchiopexy can also increase the risk of undescended testis. ${ }^{14)}$

\section{Classification}

Testicular position is classified as intra-abdominal, inguinal, supra-scrotal, high scrotal, and scrotal according to the process of testicular descent. ${ }^{14,15)}$ Intra-abdominal testis is not palpable. Inguinal testis is sometimes palpable. Supra-scrotal and high scrotal testes are palpable. Scrotal testis is considered normal, as it lies in the bottom of the scrotum (Fig. 1).

Undescended testis is classified according to its location and presence (Table 1). In palpable undescended testis, the testis may be palpable in the inguinal canal or ectopic area such as the inner thigh, femoral, pubic, and perineal regions. In impalpable undescended testis, the testis may be located in the abdomen, inguinal canal, or internal inguinal ring. It may also be absent. When the testis is found in the scrotum, sometimes in a supra- scrotal position, it is called retractile testis and has finished its descent. It can be pulled gently to the bottom of the scrotum and may stay there for a while, which is often considered normal. 16) However, up to one-third of retractile testis can reascend and become undescended, which is not considered normal. ${ }^{3)}$ Reascended testis, which a previously descended testis ascends to a higher position, comprises some proportion of cases of undescended testis. An abnormally persistent fibrotic remnant of the processus vaginalis, ${ }^{17)}$ patent processus vaginalis, and nonorthotopic gubernacular insertion (higher insertion) ${ }^{18)}$ are suggested causes of reascended testis.

\section{Diagnosis}

The external genitalia must be inspected thoroughly, especially in patients whose bilateral testes are not palpable. Bilateral impalpable testes can be associated with hormonal failure, conditions such as prune belly syndrome, a posterior urethral valve, abdominal wall defects, or neural tube defects. ${ }^{19)}$ The patient's groin and scrotum must be palpated from the inguinal canal toward the pubis in a supine or frog-leg position with warm fingers. The inner thigh, femoral, pubic, perineal, and penile regions also must be palpated to find the ectopic testis. Testis can become palpable in a sitting or squatting position but not in a supine position. ${ }^{20)}$

Unilateral impalpable testis associated with contralateral compensatory hypertrophy suggests the absence of the ipsilateral testis, meaning vanishing testis or testicular regression..$^{21,22)}$ Antenatal vascular accident ${ }^{23}$ and underlying antenatal endocri-

Table 1. Classification of undescended testes

\begin{tabular}{llc}
\hline Classification & \multicolumn{2}{c}{ Location of testis } \\
\hline Palpable & Inguinal, retractile, ectopic & - \\
Impalpable & Intra-abdominal, inguinal, ectopic & Absent \\
\hline
\end{tabular}

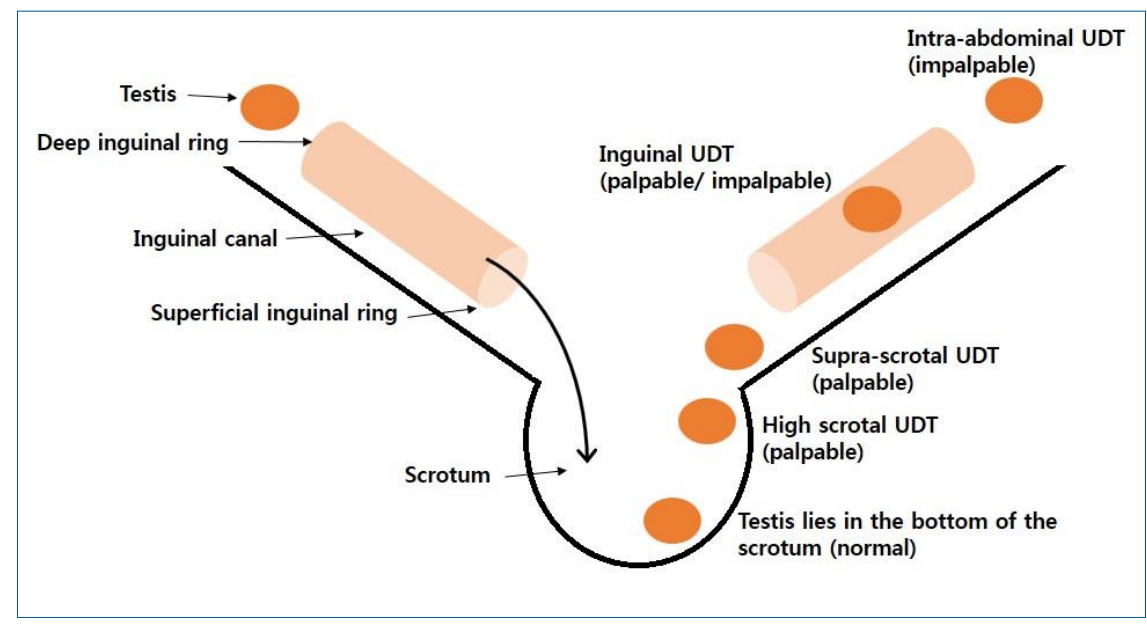

Fig. 1. Testicular position. Testicular position is classified as intra-abdominal, inguinal, suprascrotal, high scrotal, and scrotal according to the process of testicular descent. Intra-abdominal testes are not palpable. Inguinal testes are sometimes palpable. Suprascrotal and high scrotal testis is palpable. Scrotal testis is considered normal as it lies in the bottom of scrotum. UDT, undescended testis. 
nopathy are 2 suggested important pathogeneses of testicular regression. Antenatal vascular accident is caused by arrested endothelial cell migration and disturbed endothelial cell development rather than testicular torsion. ${ }^{24)}$ However, intrauterine torsion of the gonadal vessel and failure of the intrauterine testicular blood supply may also cause testicular agenesis or in utero infarction and atrophy of normal testis, resulting in vanishing testis or testicular regression. ${ }^{3,25)}$ The prevalence of monorchidism (unilateral absent testis) is up to 4\%, while that of anorchidism (bilateral absent testes) is less than $1 \%$ among patients with undescended testis. ${ }^{3)}$

Female infants presenting with bilateral inguinal hernia may be androgen insensitivity syndrome male with inguinal undescended testis. ${ }^{26,27)}$ Inguinal hernia or mass in infancy is among the most common presentations of androgen insensitivity syndrome, although it is usually diagnosed at adolescence with primary amenorrhea. Some researchers recommend chromosomal analysis in female infants with bilateral inguinal masses to diagnose androgen insensitivity syndrome. ${ }^{27)}$

Transverse testicular ectopia is a rare condition in which both testes migrate through one inguinal canal caused by a disturbance in testicular descent. ${ }^{28,29)}$ Unilateral impalpable testis and contralateral inguinal hernia are common presentation of transverse testicular ectopia. Most of the patients are diagnosed during surgery for inguinal hernia, at which time the testes are placed in one hemiscrotum. Diagnostic exploratory laparoscopy is helpful for detecting associated anomalies. ${ }^{28)}$

Routine endocrine assessment of unilateral undescended testis is not recommended. However, an endocrine assessment for bilateral undescended testes is required based on guidelines from the American Urological Association (AUA), ${ }^{30)}$ the British Association of Pediatric Surgeons/British Association of Urologic Surgeons (BAPS/BAUS), ${ }^{31)}$ the Canadian Urological Association (CUA), ${ }^{32)}$ and the European Association of Urology (EAU) ${ }^{33)}$ (Table 2). Diagnostic exploratory laparoscopy is recommended to identify impalpable undescended testis, which is the gold standard with great sensitivity and specificity. ${ }^{30-33)}$

\section{Imaging studies}

In a systemic review, ultrasonography could not determine whether a testis is present or localize impalpable testes. It also could not rule out an intra-abdominal testis. ${ }^{34)}$ Similarly, in cases of impalpable undescended testis, diagnostic accuracy of ultrasonography or magnetic resonance imaging is low to determine the presence of the testis or the absence of intra-abdominal testis. ${ }^{35-37)}$ The AUA, ${ }^{30)}$ BAPS/BAUS, ${ }^{31)} \mathrm{CUA},{ }^{32)}$ and EAU 33) guidelines do not recommend ultrasonography or other diagnostic imaging, although the former is not invasive, because it cannot add diagnostic accuracy or change treatment (Table 2).

Some practitioners perform ultrasonography to evaluate undescended testis before and after orchiopexy. ${ }^{38)}$ Practically, ultrasonography is used because of uncertainty of the diagnosis. According to the nationwide questionnaire detailing the practice patterns of undescended testis in Korea (distributed to 167 Korean urologists), most urologists performed diagnostic imaging studies for unilateral impalpable undescended testis. ${ }^{39}$ ) Fifty-two percent performed ultrasonography alone, while 40\% performed ultrasonography and other imaging studies such as magnetic resonance imaging or computed tomography. The suggested reasons for performing imaging studies were that they may add objective assessments of pre- and postoperative testicular size and help any legal problem following orchiopexy. Only $8 \%$ did not perform imaging studies, citing that imaging studies cannot change management and diagnostic exploratory laparoscopy is inevitable regardless of the results (Table 3).

\section{Hormonal therapy}

Human chorionic gonadotrophin (hCG) stimulates testicular hormone synthesis and enables the testes to descend into the scrotum. Intramuscular hCG therapy was first introduced in 1930 to treat undescended testis. However, hCG therapy can cause germ cell apoptosis, penile growth, pubic hair, frequent erection, behavior problems, and injection site pain in up to $75 \%$ of patients. ${ }^{40-42)}$ There is a lack of documentation to prove the long-term efficacy of hCG therapy. A significant reascending rate after descending has been reported. ${ }^{43)}$ Thus, hCG therapy is not justified anymore for undescended testis. ${ }^{44)}$ Intranasal gonadotrophin releasing hormone $(\mathrm{GnRH})$ analog was introduced in 1974. The success rate of testicular descent with intranasal luteinizing hormone-releasing hormone (LHRH) therapy was as

Table 2. Diagnostic guidelines of undescended testes

\begin{tabular}{|c|c|c|c|c|}
\hline & $A \cup A^{30)}$ & BAPS/BAUS ${ }^{31)}$ & $\mathrm{CUA}^{32)}$ & $E A U^{33)}$ \\
\hline Surgical specialist referral & $\begin{array}{l}\text { If there is no descent by } 6 \\
\text { months, or if UDT is newly } \\
\text { diagnosed }>6 \text { months of age. }\end{array}$ & $\begin{array}{l}\text { If there is no descent by } \\
6 \text { months. }\end{array}$ & $\begin{array}{l}\text { If there is no descent by } 6 \\
\text { months, or if UDT is newly } \\
\text { diagnosed }>6 \text { months of age. }\end{array}$ & $\begin{array}{l}\text { If there is no descent by } \\
6 \text { months. }\end{array}$ \\
\hline $\begin{array}{l}\text { Endocrine assessment for } \\
\text { bilateral UDT }\end{array}$ & Recommended & Recommended & Recommended & Recommended \\
\hline $\begin{array}{l}\text { Diagnostic exploratory laparo- } \\
\text { scopy for impalpable UDT }\end{array}$ & Recommended & Recommended & Recommended & Recommended \\
\hline Imaging study & Not recommended & Not recommended & Not recommended & Not recommended \\
\hline
\end{tabular}

AUA, American Urological Association; BAPS/BAUS, British Association of Pediatric Surgeons/British Association of Urologic Surgeons; CUA, Canadian Urological Association; EAU, European Association of Urology; UDT, undescended testis. 
low as about $20 \%$ in prescrotal or inguinal palpable undescended testis, but not in impalpable testis. ${ }^{41)}$ However, LHRH therapy can cause hydrocele requiring surgery, penile growth, pubic hair, frequent erection, and behavioral problems. ${ }^{41)} \mathrm{GnRH} / \mathrm{LHRH}$ therapy can also harm germ cells and suppress their numbers. ${ }^{45}$ ) Long-term follow-up of GnRH/LHRH therapy has not been reported yet. Besides, the success rate of testicular descent with hormonal therapy is low and the risk of testicular reascending is high, although the testes descend with hormone therapy. On the other hand, in a small study of 10 boys, GnRH agonist therapy with orchiopexy improved impaired mini-puberty and spermatogonia in patients with bilateral undescended testes. ${ }^{46)}$

According to international guidelines, routine hormonal therapy with hCG or GnRH/LHRH for undescended testes. is not recommended due to the lack of evidence as previously described (Table 4). ${ }^{30,32,33)}$ Consensus is developing that orchiopexy but not hormonal therapy is required in the first year of life. ${ }^{30,47,48)}$ In an identified hormonal defect in congenital hypogonadotropic hypogonadism or partial androgen insensi-

Table 3. Diagnostic imaging studies for undescended testes

\begin{tabular}{l}
\hline Imaging study is not recommended ${ }^{30-33)}$ \\
\hline Reasons 1. Imaging study cannot add diagnostic accuracy \\
1) High false negative rate (low sensitivity) if the size of \\
testis is small \\
2) Cannot determine whether a testis is present or not \\
3) Cannot localize impalpable testes \\
4) Cannot rule out an intra-abdominal testis \\
2. Imaging study cannot change management \\
3. Diagnostic exploratory laparoscopy is inevitable regardless \\
of the result of imaging study.
\end{tabular}
Practitioners perform imaging study 38,39 )

Reasons 1. Imaging study may add objective assessment of preoperative testicular position and size.

2. Imaging study may add objective assessment of postoperative testicular size.

3. Imaging study may be helpful for any legal problem following orchiopexy.

1) Can provide objective size of testis or atrophied testis before orchiopexy tivity, hormonal therapy can be considered by a pediatric endocrinologist. However, debate persists over whether hormonal therapy is useful as an adjunct to orchiopexy to stimulate germ cell development, although hormonal therapy for undescended testes is ineffective.

\section{Surgical therapy}

If the testes do not descend at 6 months of age, the probability of spontaneous descent thereafter is low. ${ }^{49)}$ International guidelines recommend surgical specialist referral from primary caregivers if descent does not occur by 6 months, ${ }^{30-33)}$ or if undescended testis is newly diagnosed after 6 months of age (Table 2). ${ }^{30,32)}$

Undescended testis interferes with the differentiation of primitive germ cells that produce germ cells and finally spermatogenesis. ${ }^{44)}$ Thus, delayed orchiopexy decreases germ cell production, testicular volume, and fertility. ${ }^{50)}$ To enhance spermatogenesis and increase testicular volume, the recommended age of orchiopexy decreased from 48-72 months in 1986 to 18-24 months and recently 6-12 months of age. ${ }^{51,52)}$ However, large number of boys still undergo orchiopexy after 18 months of age. The median age for orchiopexy was 48 months between 1993 and 2000 and 36 months between 2000 and 2010 in 3784 orchiopexies over 22 years. ${ }^{51)}$ The most common age at orchiopexy was 12-18 months. The second most common age was 18-30 months between 1993 and 2014. ${ }^{51)}$ Among patients undergoing orchiopexy, $77 \%$ were older than 1 year and $42 \%$ were older than 2 years at orchiopexy. ${ }^{6}$

Histological evidence suggests that orchiopexy should be performed within the first year of life (no later than 2 years of age) to protect fertility. ${ }^{53)}$ A recent systematic review found no difference in testicular volume or spermatogonia in orchiopexy before versus after 1 year of age, although better fertility potential with orchiopexy performed before 1 year of age was found. ${ }^{54)}$ To protect fertility potential and decrease malignant changes, surgical exploration and orchiopexy are recommended between

Table 4. Treatment guidelines and outcomes of undescended testes

\begin{tabular}{|c|c|c|c|c|}
\hline & $A \cup A^{30)}$ & BAPS/BAUS ${ }^{31)}$ & CUA $^{32)}$ & $E A U^{33)}$ \\
\hline Hormonal therapy & Not recommend & Not discussed & Not recommend & Not recommend \\
\hline Age at orchiopexy & $\begin{array}{l}\text { If no descent by } 6 \text { months, sur- } \\
\text { gery should be done within the } \\
\text { next year. }\end{array}$ & $6-18$ months of age & $6-18$ months of age & $\begin{array}{l}6-12 \text { months of age ( }<12 \text { months of } \\
\text { age, by } 18 \text { months at the latest) }\end{array}$ \\
\hline Fertility & $\begin{array}{l}\text { Decreased fertility and paternity } \\
\text { in bilateral UDT }\end{array}$ & Not discussed & $\begin{array}{l}\text { Decreased paternity in bilateral } \\
\text { UDT }\end{array}$ & $\begin{array}{l}\text { Decreased fertility and paternity in } \\
\text { bilateral UDT, age at orchiopexy is } \\
\text { important. }\end{array}$ \\
\hline Testicular cancer & $\begin{array}{l}\text { Increased risk in intra-abdominal } \\
\text { UDT, decreased risk in orchio- } \\
\text { pexy before puberty (compared } \\
\text { to orchiopexy after puberty) }\end{array}$ & Not discussed & $\begin{array}{l}\text { Decreased risk in orchiopexy } \\
\text { before puberty, but still above } \\
\text { that of noncryptorchid male }\end{array}$ & $\begin{array}{l}\text { Increased risk of testicular cancer, } \\
\text { decreased risk in orchiopexy before } \\
\text { puberty (compared to orchiopexy } \\
\text { after puberty) }\end{array}$ \\
\hline $\begin{array}{l}\text { Self-examination } \\
\text { after puberty }\end{array}$ & Recommended (monthly) & Not discussed & $\begin{array}{l}\text { Recommended, no need for long- } \\
\text { term urological follow-up }\end{array}$ & Recommended \\
\hline
\end{tabular}

AUA, American Urological Association; BAPS/BAUS, British Association of Pediatric Surgeons/British Association of Urologic Surgeons; CUA, Canadian Urological Association; EAU, European Association of Urology; UDT, undescended testis. 
six and 18 months of age (Table 4).

Testicular torsion, a surgical emergency, is not common in neonates, and torsion of undescended testis does not present the typical painful swelling of the scrotum; rather, it appears as swelling of the groin. Therefore, torsion of undescended testis is not easy to recognize. Undescended testis and an ipsilateral inguinal mass with groin swelling must be suspected as torsion of undescended testis. Ultrasonography is not helpful to differentiate between incarcerated inguinal hernia and torsion of undescended testis; rather, urgent referral and surgical exploration are required. .5) $^{55}$

\section{Undescended testis and fertility}

Hutson et al. ${ }^{56)}$ reported that gonocytes transform into spermatogenic stem cells at 3-9 months of age. This postnatal step is confused in cases of undescended testis. Arrested gonocytes in undescended testis can cause germ cell malignancies after puberty. Abnormalities in gonocyte transformation can cause infertility. Thus, the original location of the undescended testis is important in the risk of testicular cancer and fertility. Age at orchiopexy is also an important factor for predicting fertility. ${ }^{33)}$

Compared to fertility rate (number of offspring born per mating pair) in the general population, that in patients with undescended testis is decreased, although they underwent orchiopexy. Patients with bilateral undescended testes have an increased infertility rate compared to those with a unilateral undescended testis and the general population. ${ }^{57)}$ Infertility rates of patients with unilateral undescended testis are up to $10 \%$, which is even higher in patients with bilateral undescended testes. ${ }^{58,59)}$ The paternity rate (actual potential of fatherhood) was reportedly $62 \%$ in bilateral undescended testes, $89 \%$ in unilateral undescended testis, and $94 \%$ in the general United States population. ${ }^{60)}$ The paternity rate among patients with bilateral undescended testes was as low as 33\%-65\% in Canada. In cases of unilateral undescended testis, it was similar to that in a general Canadian population (up to 90\%). ${ }^{32}$ Testicular atrophy has been reported in less than one third of patients, depending on the original location, despite the success of surgical procedures. ${ }^{49)}$ Intra-abdominal undescended testis is associated with a high risk of postsurgical atrophy despite successful orchiopexy, which is 15 -fold higher than inguinal undescended testis. ${ }^{58)}$ Untreated bilateral undescended testes show a $100 \%$ oligospermia rate. ${ }^{61)}$ Patients with bilateral undescended testes without germ cells on biopsy show a $75 \%-100 \%$ risk of infertility. ${ }^{62)}$

\section{Undescended testis and testicular cancer}

In a meta-analysis, patients with undescended testis are at a threefold increased risk of testicular cancer later in life. ${ }^{7)}$ In another study, the risk of testicular cancer is increased sevenfold in patients with undescended testes and 32-fold if orchiopexy is delayed after puberty. ${ }^{63)}$ A significantly increased risk of testicular cancer in intra-abdominal testis was reported in the past. However, the risk of testicular cancer decreased in patients who underwent orchiopexy before puberty compared to those who underwent orchiopexy after puberty. ${ }^{30,63,64)}$ The relative risk of testicular cancer in patients who underwent orchiopexy before puberty ( $<13$ years of age) was 2.2 , which increased to 5.4 in patients who underwent orchiopexy after puberty versus the general population. ${ }^{64)}$

Formal long-term urological follow-up of patients with undescended testes is not recommended. ${ }^{32)}$ Screening and selfexamination during and after puberty are recommended because of the increased risk of testicular cancer (Table 4).

\section{Conclusion}

Timely referral to a surgical specialist and timely surgical correction may improve fertility and decrease malignancy rates related to undescended testis. Primary caregivers should consider surgical specialist referral of patients with undescended testis if no descent occurs by 6 months, undescended testis is newly diagnosed after 6 months of age, or testicular torsion is suspected. The use of ultrasonography and other diagnostic imaging techniques is not recommended because they cannot add diagnostic accuracy or change treatment. Orchiopexy is recommended between 6 and 18 months at the latest. The fertility rate is low in patients with bilateral undescended testes, although orchiopexy is successful. The risk of testicular cancer in patients with undescended testis is increased compared to that in the general population. The original location of the testes and the age at orchiopexy are predictive factors for fertility and malignancy later in life. Self-examination after puberty is recommended to facilitate early cancer detection.

\section{Conflict of interest}

No potential conflict of interest relevant to this article was reported.

See the commentary "Undescended testis: importance of a timely referral to a surgical specialist" via https://doi.org/ 10.3345/cep.2020.00115.

\section{References}

1. Sijstermans K, Hack WW, Meijer RW, van der Voort-Doedens LM. The frequency of undescended testis from birth to adulthood: a review. Int J Androl 2008;31:1-11.

2. Holland AJ, Nassar N, Schneuer FJ. Undescended testes: an update. Curr Opin Pediatr 2016;28:388-94.

3. Radmayr C, Dogan HS, Hoebeke P, Kocvara R, Nijman R, Silay S, et al. Management of undescended testes: European Association of Urology/ European Society for Paediatric Urology Guidelines. J Pediatr Urol 2016; 12:335-43.

4. Boisen KA, Kaleva M, Main KM, Virtanen HE, Haavisto AM, Schmidt 
IM, et al. Difference in prevalence of congenital cryptorchidism in infants between two Nordic countries. Lancet 2004;363:1264-9.

5. Kuiri-Hanninen T, Koskenniemi J, Dunkel L, Toppari J, Sankilampi U. postnatal testicular activity in healthy boys and boys with cryptorchidism. Front Endocrinol (Lausanne) 2019;10:489.

6. Nah SA, Yeo CS, How GY, Allen JC, Jr., Lakshmi NK, Yap TL, et al. Undescended testis: 513 patients' characteristics, age at orchidopexy and patterns of referral. Arch Dis Child 2014;99:401-6.

7. Lip SZ, Murchison LE, Cullis PS, Govan L, Carachi R. A meta-analysis of the risk of boys with isolated cryptorchidism developing testicular cancer in later life. Arch Dis Child 2013;98:20-6.

8. Cook MB, Akre O, Forman D, Madigan MP, Richiardi L, McGlynn KA. A systematic review and meta-analysis of perinatal variables in relation to the risk of testicular cancer--experiences of the son. Int J Epidemiol 2010;39:1605-18.

9. Mavrogenis S, Urban R, Czeizel AE. Characteristics of boys with the socalled true undescended testis diagnosed at the third postnatal month-a population-based case-control study. J Matern Fetal Neonatal Med 2015;28:1152-7.

10. Gurney JK, McGlynn KA, Stanley J, Merriman T, Signal V, Shaw C, et al. Risk factors for cryptorchidism. Nat Rev Urol 2017;14:534-48.

11. McGlynn KA, Graubard BI, Klebanoff MA, Longnecker MP. Risk factors for cryptorchism among populations at differing risks of testicular cancer. Int J Epidemiol 2006;35:787-95.

12. Hackshaw A, Rodeck C, Boniface S. Maternal smoking in pregnancy and birth defects: a systematic review based on 173687 malformed cases and 11.7 million controls. Hum Reprod Update 2011;17:589-604.

13. Zhang L, Wang XH, Zheng XM, Liu TZ, Zhang WB, Zheng H, et al. Maternal gestational smoking, diabetes, alcohol drinking, pre-pregnancy obesity and the risk of cryptorchidism: a systematic review and metaanalysis of observational studies. PLoS One 2015;10:e0119006.

14. Cho A, Thomas J, Perera R, Cherian A. Undescended testis. BMJ 2019; 364:1926.

15. Cryptorchidism: a prospective study of 7500 consecutive male births, 1984-8. John Radcliffe Hospital Cryptorchidism Study Group. Arch Dis Child 1992;67:892-9.

16. Keys C, Heloury Y. Retractile testes: a review of the current literature. J Pediatr Urol 2012;8:2-6.

17. Yeap E, Nataraja RM, Pacilli M. Undescended testes: what general practitioners need to know. Aust J Gen Pract 2019;48:33-6.

18. Haid B, Silay MS, Radford A, Rein P, Banuelos B, Oswald J, et al. Late ascended testes: is non-orthotopic gubernacular insertion a confirmation of an alternative embryological etiology? J Pediatr Urol 2019;15:71.e1-6.

19. Hutson JM, Balic A, Nation T, Southwell B. Cryptorchidism. Semin Pediatr Surg 2010;19:215-24.

20. Cendron M, Huff DS, Keating MA, Snyder HM 3rd, Duckett JW. Anatomical, morphological and volumetric analysis: a review of 759 cases of testicular maldescent. J Urol 1993;149:570-3.

21. Braga LH, Kim S, Farrokhyar F, Lorenzo AJ. Is there an optimal contralateral testicular cut-off size that predicts monorchism in boys with nonpalpable testicles? J Pediatr Urol 2014;10:693-8.

22. Haid B, Rein P, Oswald J. Undescended testes: diagnostic algorithm and treatment. Eur Urol Focus 2017;3:155-7.

23. Ito $\mathrm{Y}$, Kitamura $\mathrm{H}$. Antenatal ultrasound visualization of left testis that then vanished after birth. Pediatr Int 2014;56:928-30.

24. Dangle P, Salgado C, Reyes-Mugica M, Schneck F, Ost M, Sims-Lucas S. Testicular hypoplasia is driven by defective vascular formation. Urology 2017;101:94-8.

25. Ganni P, Vachhani N, Udayasankar U. Intrauterine testicular torsion. J Urol 2014;191:217-8.

26. Yoshii K, Naiki Y, Terada Y, Fukami M, Horikawa R. Mismatch between fetal sexing and birth phenotype: a case of complete androgen insensitivity syndrome. Endocr J 2018;65:221-5.

27. Deeb A, Hughes IA. Inguinal hernia in female infants: a cue to check the sex chromosomes? BJU Int 2005;96:401-3.

28. Raj V, Redkar R, Krishna S, Tewari S. Rare case of transverse testicular ectopia - case report and review of literature. Int J Surg Case Rep 2017;
41:407-10.

29. Naji H, Peristeris A, Stenman J, Svensson JF, Wester T. Transverse testicular ectopia: three additional cases and a review of the literature. Pediatr Surg Int 2012;28:703-6.

30. Kolon TF, Herndon CD, Baker LA, Baskin LS, Baxter CG, Cheng EY, et al. Evaluation and treatment of cryptorchidism: AUA guideline. J Urol 2014;192:337-45.

31. British Association of Pediatric Surgeons. Commissioning guide: paediatric orchidopexy for undescended testis. London: Royal College of Surgeons of England (RCS); British Association of Urological Surgeons (BAUS), 2015.

32. Braga LH, Lorenzo AJ, Romao RLP. Canadian Urological AssociationPediatric Urologists of Canada (CUA-PUC) guideline for the diagnosis, management, and followup of cryptorchidism. Can Urol Assoc J 2017; 11:E251-60.

33. Radmayr C, Bogaert G, Dogan HS, Kočvara R, Nijman JM, Stein R, et al. EAU Guidelines on Paediatric Urology 2018. Arnhem (The Netherlands): European Association of Urology; European Society for Paediatric Urology, 2018.

34. Tasian GE, Copp HL. Diagnostic performance of ultrasound in nonpalpable cryptorchidism: a systematic review and meta-analysis. Pediatrics 2011;127:119-28.

35. Tasian GE, Yiee JH, Copp HL. Imaging use and cryptorchidism: determinants of practice patterns. J Urol 2011;185:1882-7.

36. Elder JS. Ultrasonography is unnecessary in evaluating boys with a nonpalpable testis. Pediatrics 2002;110:748-51.

37. Esposito C, Escolino M, Savanelli A, Alicchio F, Roberti A, Settimi A. Ultrasonography is unnecessary and misleading in evaluating boys with a nonpalpable testis and can be a cause of a legal process. Med Sci Law 2013;53:247-8.

38. Jedrzejewski G, Wieczorek AP, Osemlak P, Nachulewicz P. The role of ultrasound in the management of undescended testes before and after orchidopexy - an update. Medicine (Baltimore) 2016;95:e5731.

39. Lee SW, Kim KS, Chang HS, Ryu DS. Comprehension and practice patterns toward cryptorchidism in Korean Urologists. Korean J Urol 2009;50:169-78.

40. Chua ME, Mendoza JS, Gaston MJ, Luna SL Jr., Morales ML Jr. Hormonal therapy using gonadotropin releasing hormone for improvement of fertility index among children with cryptorchidism: a metaanalysis and systematic review. J Pediatr Surg 2014;49:1659-67.

41. Li T, Gao L, Chen P, Bu S, Cao D, Yang L, et al. A systematic review and meta-analysis of comparative studies assessing the efficacy of luteinizing hormone-releasing hormone therapy for children with cryptorchidism. Int Urol Nephrol 2016;48:635-44.

42. Hjertkvist M, Lackgren G, Ploen L, Bergh A. Does HCG treatment induce inflammation-like changes in undescended testes in boys? J Pediatr Surg 1993;28:254-8.

43. Waldschmidt J, el-Dessouky M, Priefer A. Therapeutic results in cryptorchidism after combination therapy with LH-RH nasal spray and hCG. Eur J Pediatr 1987;146 Suppl 2:S31-4.

44. Ong C, Hasthorpe S, Hutson JM. Germ cell development in the descended and cryptorchid testis and the effects of hormonal manipulation. Pediatr Surg Int 2005;21:240-54.

45. Cortes D, Thorup J, Visfeldt J. Hormonal treatment may harm the germ cells in 1 to 3-year-old boys with cryptorchidism. J Urol 2000;163:12902.

46. Vincel B, Verkauskas G, Bilius V, Dasevicius D, Malcius D, Jones B, et al. Gonadotropin-releasing hormone agonist corrects defective mini-puberty in boys with cryptorchidism: a prospective randomized study. Biomed Res Int 2018;2018:4651218.

47. Hutson JM, Thorup J. Evaluation and management of the infant with cryptorchidism. Curr Opin Pediatr 2015;27:520-4.

48. Steinbrecher $\mathrm{H}$. The undescended testis: working towards a unified care pathway for 2014. Arch Dis Child 2014;99:397-8.

49. Schneuer FJ, Holland AJ, Pereira G, Jamieson S, Bower C, Nassar N. Age at surgery and outcomes of an undescended testis. Pediatrics 2016; 137:e20152768. 
50. Chan E, Wayne C, Nasr A. Ideal timing of orchiopexy: a systematic review. Pediatr Surg Int 2014;30:87-97.

51. Wei Y, Wu SD, Wang YC, Lin T, He DW, Li XL, et al. A 22-year retrospective study: educational update and new referral pattern of age at orchidopexy. BJU Int 2016;118:987-93.

52. Ritzen EM, Bergh A, Bjerknes R, Christiansen P, Cortes D, Haugen SE, et al. Nordic consensus on treatment of undescended testes. Acta Paediatr 2007;96:638-43.

53. Park KH, Lee JH, Han JJ, Lee SD, Song SY. Histological evidences suggest recommending orchiopexy within the first year of life for children with unilateral inguinal cryptorchid testis. Int J Urol 2007;14:616-21.

54. Allin BSR, Dumann E, Fawkner-Corbett D, Kwok C, Skerritt C. Systematic review and meta-analysis comparing outcomes following orchidopexy for cryptorchidism before or after 1 year of age. BJS Open 2018; 2:1-12.

55. Kargl S, Haid B. Torsion of an undescended testis - a surgical pediatric emergency. J Pediatr Surg 2020;55:660-4.

56. Hutson JM, Li R, Southwell BR, Petersen BL, Thorup J, Cortes D. Germ cell development in the postnatal testis: the key to prevent malignancy in cryptorchidism? Front Endocrinol (Lausanne) 2012;3:176.

57. Gracia J, Sanchez Zalabardo J, Sanchez Garcia J, Garcia C, Ferrandez A. Clinical, physical, sperm and hormonal data in 251 adults operated on for cryptorchidism in childhood. BJU Int 2000;85:1100-3.

58. Carson JS, Cusick R, Mercer A, Ashley A, Abdessalam S, Raynor S, et al. Undescended testes: does age at orchiopexy affect survival of the testis? J
Pediatr Surg 2014;49:770-3.

59. Murphy F, Paran TS, Puri P. Orchidopexy and its impact on fertility. Pediatr Surg Int 2007;23:625-32.

60. Lee PA, O'Leary LA, Songer NJ, Coughlin MT, Bellinger MF, LaPorte RE. Paternity after unilateral cryptorchidism: a controlled study. Pediatrics 1996;98:676-9.

61. Lee PA. Fertility after cryptorchidism: epidemiology and other outcome studies. Urology 2005;66:427-31.

62. Cortes D, Thorup JM, Beck BL. Quantitative histology of germ cells in the undescended testes of human fetuses, neonates and infants. J Urol 1995;154:1188-92.

63. Walsh TJ, Dall'Era MA, Croughan MS, Carroll PR, Turek PJ. Prepubertal orchiopexy for cryptorchidism may be associated with lower risk of testicular cancer. J Urol 2007;178:1440-6; discussion 6.

64. Pettersson A, Richiardi L, Nordenskjold A, Kaijser M, Akre O. Age at surgery for undescended testis and risk of testicular cancer. N Engl J Med 2007;356:1835-41.

How to cite this article: Shin J, Jeon GW. Comparison of diagnostic and treatment guidelines for undescended testis. Clin Exp Pediatr 2020;63:415-21. https://doi.org/10.3345/cep. 2019.01438 